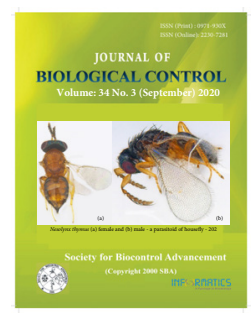

Research Article

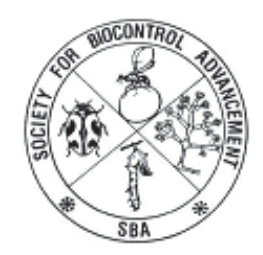

\title{
Evaluation of Beauveria bassiana and Metarhizium anisopliae isolates against Plutella xylostella (L.) under laboratory conditions
}

\author{
BATHINA POORNESHA ${ }^{1,2^{*}}$ and BONAM RAMANUJAM ${ }^{1}$ \\ ${ }^{1}$ ICAR-National Bureau of Agricultural Insect Resources, Post Bag No. 2491, H.A. Farm Post, Bellary Road, Bengaluru - \\ 560024, Karnataka, India \\ ${ }^{2}$ Department of Biotechnology, Center for Post Graduate Studies, Jain University, Jayanagar, Bengaluru - 560011, Karnataka, \\ India \\ *Corresponding author Email: poorniintbiotech@gmail.com
}

\begin{abstract}
Twenty isolates each of Beauveria bassiana and Metarhizium anisopliae were tested against the second instar larvae of Plutella xylostella through laboratory bioassay using larval dip method at the concentration of $1 \times 10^{7}$ conidia/ml. Higher larval mortality of $88.85 \%$ and $81.44 \%$, were observed with NBAIR Ma-4 and NBAIR Ma-35 isolates of $M$. anisopliae and 77.36\% with NBAIR-Bb-5a isolate of $B$. bassiana. Further studies on dose and time mortality with four isolates indicated lowest $\mathrm{LC}_{50}$ value of $2.6 \times 10^{4}$ conidia/ml and $\mathrm{LT}_{50}$ of 86.6 hours with NBAIR Ma-35 isolate. These isolates have to be further tested against P. xylostella in infested fields of cabbage and cauliflower.
\end{abstract}

KEY WORDS: Beauveria bassiana, Entomopathogenic fungi, Metarhizium anisopliae, Plutella xylostella

(Article chronicle: Received: 05-08-2020; Revised: 24-09-2020; Accepted: 27-09-2020)

\section{INTRODUCTION}

Plutella xylostella (L.) (Diamond Back Moth (DBM)) (Lepidoptera: Plutellidae) is widely distributed serious pest of cruciferous crops and causes extensive loss of US\$4-5 billion globally (Zalucki et al., 2012; Furlong et al., 2013). In India, cabbage and cauliflower are important cole crops grown in 0.438 million hectares and producing 6.335 million tonnes per annum. The losses in cabbage and cauliflower due to DBM attack in India was estimated at 35 percent even with the use of insecticides and could go upto 90 per cent without following control measures (Mohan \& Gujar, 2003). Krishnamurthy (2004) reported 52\% yield loss of cabbage due to the attack of diamondback moth in India. This pest is mainly controlled using chemical insecticides and the pest has developed resistance to all categories of chemical insecticides (McCann et al., 2001; Liu et al., 2003) and also to the toxins of the Bacillus thuringiensis. Apart from this, chemical insecticides are detrimental to the natural enemies of this pest and also to other living organisms. Hence, alternative control measures are required for safer and costeffective management of this destructive pest (Bert, 2006).

Entomopathogenic fungi can be considered as one of the alternative approaches as biocontrol agents for insect pests (Sheeba et al., 2001). The present study was taken up to identify promising isolates of $B$. bassiana and M. anisopliae against $P$. xylostella.

\section{MATERIALS AND METHODS}

Preliminary screening was carried out with twenty isolates each of Beauveria bassiana and Metarhizium anisopliae on the second instar larvae of P. xylostella using laboratory bioassay method for identification of promising isolates.

\section{Insect rearing}

A starter culture of DBM moths were obtained from ICAR-National Bureau of Agricultural Insect Resources (NBAIR) for rearing the larvae of P. xylostella on mustard seedlings (Liu \& Sun, 1984). Mustard seedlings were raised in plastic cups $(55.2 \times 68.9 \times 45.1 \mathrm{~mm})$ on vermiculate at $25-27^{\circ}$ $\mathrm{C}$ and $70 \% \mathrm{RH}$. Four-days old-mustard seedlings thus raised in cups were placed in acrylic cages $(24 \times 24 \times 24$ ") and DBM moths were released in the cages for oviposition. After 24-48 hours, the cups were removed and kept in trays for egg hatch and larval development. Fresh seedlings were again provided for the moths to oviposition. The mustard seedlings containing 2nd instar larvae of P. xylostella were used in this study. 


\section{Fungal culture}

Twenty isolates each of B. bassiana and M. anisopliae collected from different insect hosts and soils from various geographical areas of India maintained at the culture repository of National Bureau of Agricultural Insect Resources (ICAR-NBAIR), Bangalore were used for preliminary screening against $P$. xylostella. Fungal culture of each isolate is grown on Sabouraud's Dextrose Yeast extract Broth (SDYB) medium (Dextrose 20g, Mycological peptone $10 \mathrm{~g}$, yeast extract $5 \mathrm{~g}$, in $1 \mathrm{~L}$ of distilled water). Conidiated rice was produced by inoculating 4 days old shaker culture to sterilized rice bag and incubated for 15 days at $26 \pm$ $1{ }^{\circ} \mathrm{C}$. Conidial suspension of each isolate was prepared by suspending one gram of 15 days old conidiated rice in sterile distilled water with $0.01 \%$ Tween 80 . The suspension was filtrated through three layers of muslin cloth to get hyphalfree conidial suspension. The conidial concentration in the suspension was adjusted to $1 \times 10^{7}$ conidia/ml using Neubauer $\mathrm{s}$ improved haemocytometer.

\section{Laboratory bioassay}

Thirty larvae of $P$. xylostella were dipped in $0.5 \mathrm{ml}$ of the spore suspension $\left(1 \times 10^{7}\right.$ conidia $\left./ \mathrm{ml}\right)$ of each of the $B$. bassiana and $M$. anisopliae isolates for 10 seconds and were later transferred to a sterile plastic container, provided with surface sterilized cabbage leaves as a food and placed at $26^{\circ} \mathrm{C}$ and $70 \% \mathrm{RH}$ in an incubation chamber. Control group of larvae were treated with distilled water containing $0.01 \%$ Tween 80 . Larval mortality was recorded for a period of 10 days at $24 \mathrm{~h}$ intervals. The percent mortality of the larvae was calculated after deducting the control mortality using Abbott's formula (Abbott, 1925). The data of mortality were subjected to the statistical analysis using analysis of variance SPSS software, Version 20. Based on these studies, promising isolates were identified for further studies (Table 2).

\section{Dose and Time mortality}

For dose mortality studies $\left(\mathrm{LC}_{50}\right)$, five conidial concentrations $\left(1 \times 10^{4}, 1 \times 10^{5}, 1 \times 10^{6}, 1 \times 10^{7} \& 1 \times 10^{8}\right.$ conidia/ $\mathrm{ml}$ ) were prepared and bioassays were carried out as described above. In case of time mortality studies, $1 \times 10^{8}$ conidia $/ \mathrm{ml}$ concentration was used to determine $\mathrm{LT}_{50}$. The dose and time to kill 50 per cent of the population $\left(\mathrm{LC}_{50} \& \mathrm{LT}_{50}\right)$ was determined by probit analysis (Finney, 1971). Statistical analysis was done using SPSS windows version 20.0.

\section{RESULTS AND DISCUSSION}

\section{Laboratory bioassay}

Among the 20 isolates of $B$. bassiana tested, Bb-5a showed significantly higher mortality $(77.36 \%)$ and rest of the isolates showed 17.31-51.14\% mortality (Table 1). Among the 20 isolates of $M$. anisopliae tested, Ma-4 and Ma-35 showed significantly higher mortality (81.44 \& $88.85 \%$ respectively) and the rest of the isolates showed $36.95-70.33 \%$ mortality (Table 1 ).

Isolates of $B$. bassiana and $M$. anisopliae tested showed varying percent mortality on second instar larvae of P. xylostella. As these isolates were obtained from diverse insect hosts and soils from different climatic conditions, the variability in virulence on $P$. xylostella is expected. According to Maurer et al. (1997), the isolates which derived from the same or related host species showed higher virulence. But our studies indicated that higher virulence was observed even with the isolates that have been derived from the soil and non-related host species. Silva et al. (2003) reported

Table 1. Effect of $B$. bassiana and $M$. anisopliae isolates on the larvae of $\boldsymbol{P}$. xylostella in the laboratory bioassay

\begin{tabular}{|l|l|l|l|l|}
\hline $\begin{array}{l}\text { Sl. } \\
\text { No. }\end{array}$ & $\begin{array}{l}\text { Beauveria } \\
\text { bassiana } \\
\text { NBAIR } \\
\text { Strains }\end{array}$ & \% Mortality & $\begin{array}{l}\text { Metarhizium } \\
\text { anisopliae } \\
\text { NBAIR } \\
\text { Strains }\end{array}$ & \% Mortality \\
\hline 1. & Bb-5a & $\mathbf{7 7 . 3 6}^{\text {a }}$ & Ma-4 & $\mathbf{8 1 . 4 4}^{\text {ab }}$ \\
\hline 2. & Bb-10 & $36.07^{\text {bcde }}$ & Ma-7 & $44.52^{\text {def }}$ \\
\hline 3. & Bb-17 & $43.56^{\text {bc }}$ & Ma-8 & $70.33^{\text {abc }}$ \\
\hline 4. & Bb-18 & $36.07^{\text {bcde }}$ & Ma-10 & $51.77^{\text {cdef }}$ \\
\hline 5. & Bb-21 & $39.90^{\text {bcd }}$ & Ma-19 & $55.72^{\text {cdef }}$ \\
\hline 6. & Bb-22 & $39.82^{\text {bcd }}$ & Ma-35 & $\mathbf{8 8 . 8 5}^{\text {a }}$ \\
\hline 7. & Bb-24 & $43.56^{\text {bc }}$ & Ma-39 & $44.48^{\text {def }}$ \\
\hline 8. & Bb-26 & $39.82^{\text {bcd }}$ & Ma-43 & $36.95^{\text {f }}$ \\
\hline 9. & Bb-27 & $32.37^{\text {bde }}$ & Ma-44 & $59.21^{\text {cde }}$ \\
\hline 10. & Bb-28 & $17.31^{\text {de }}$ & Ma-45 & $48.19^{\text {def }}$ \\
\hline 11. & Bb-29 & $43.56^{\text {bc }}$ & Ma-46 & $37.07^{\text {f }}$ \\
\hline 12. & Bb-30 & $47.35^{\text {bc }}$ & Ma-47 & $51.85^{\text {cdef }}$ \\
\hline 13. & Bb-40 & $32.33^{\text {bcde }}$ & Ma-48 & $55.55^{\text {cdef }}$ \\
\hline 14. & Bb-43 & $25.47^{\text {cde }}$ & Ma-49 & $62.92^{\text {bd }}$ \\
\hline 15. & Bb-45 & $51.14^{\text {b }}$ & Ma-51 & $55.63^{\text {cdef }}$ \\
\hline 16. & Bb-51 & $39.78^{\text {bcd }}$ & Ma-53 & $48.19^{\text {def }}$ \\
\hline 17. & Bb- 55 & $47.35^{\text {bc }}$ & Ma-54 & $55.51^{\text {cdef }}$ \\
\hline 18. & Bb-57 & $51.10^{\text {b }}$ & Ma-55 & $55.51^{\text {cde }}$ \\
\hline 19. & Bb- 60 & $47.44^{\text {bc }}$ & Ma-56a & $40.86^{\text {ef }}$ \\
\hline 20. & Bb-74 & $28.50^{\text {bcde }}$ & Ma-57 & $55.51^{\text {cdef }}$ \\
\hline 21. & Control & $11.33^{\text {e }}$ & Control & $10.00^{\text {g }}$ \\
\hline & F- value & 3.428 & F- value & 5.930 \\
\hline P-value & 0.072 & P-value & 0.019 \\
\hline
\end{tabular}

*Values in columns followed by the different letter are significantly different with each other according to Tukeys test $(\mathrm{P}<0.01)$ 
$78-90 \%$ mortality of second-instar larvae of diamondback moth when treated with $B$. bassiana isolates at concentration of $10^{8}$ conidia/ml. Valda et al. (2003) reported $26-96 \%$ larval mortality of DBM with B. bassiana and M. anisopliae isolates at $10^{8}$ conidia $/ \mathrm{ml}$. In our study, M. anisopliae isolates showed higher mortality of $81-88 \%$ than $B$. bassiana isolates (51-77\%) at $10^{7}$ conidia/ml concentration. Suwannakut et al. (2005) reported that variation in virulence can be attributed due to genetic diversity of the isolates, based on insect host and geographical region. This laboratory studies helped in identifying the local promising isolates for further field testing against $P$. xylostella in crucifer's crops.

\section{Dose and Time mortality}

Among the four isolates tested, NBAIR Ma-35 showed lowest $\mathrm{LC}_{50}$ at $2.6 \times 10^{4}$ condia/ml and $\mathrm{LT}_{50}$ at the 86.6 hours against $P$. xylostella. NBAIR Ma-4 with $\mathrm{LC}_{50}$ at $5.3 \times 10^{4}$ and $\mathrm{LT}_{50}$ at 121.30 hours, NBAIR Bb-5a with $\mathrm{LC}_{50}$ at $1.3 \times 10^{5}$ and $\mathrm{LT}_{50}$ at the 100.3 hours and NBAIR Bb-45 with $\mathrm{LC}_{50}$ at $1.9 \times 10^{6}$ and $\mathrm{LT}_{50}$ at the 156.6 hours (Table $3 \& 4$ ).

Chui-Chai et al. (2012) reported $\mathrm{LT}_{50}$ ranging from 25145 hours with Beauveria spp. and Metarhizium spp. and $\mathrm{LC}_{50}$ of $2.66 \times 10^{6}$ and $3.11 \times 10^{5}$ conidia $\mathrm{ml}^{-1}$ respectively. B. bassiana and $M$. anisopliae isolates showed $\mathrm{LT}_{50}$ ranging from 0.7-5.8 days and $\mathrm{LC}_{50}$ of $1.2 \times 10^{6}$ and $8.6 \times 10^{6}{\text { conidia } \mathrm{ml}^{-1}}^{-1}$
(Valda et al., 2003). In present study, the Metarhizium anisopliae isolates showed high $\mathrm{LC}_{50}$ value at 2.6-5.3 $\times 10^{4}$ conidia/ml and $\mathrm{LT}_{50}$ of 86-121 hours. Duarte et al., 2016 stated that mortality at lower conidial concentrations is important from economic point of view which helps in product development and marketing of entomopathogenic microbes. Our results also showed 50\% mortality at $10^{4}$ conidia/ml and within 3.5 days with NBAIR Ma-35 isolate of M. anisopliae against $P$. xylostella.

\section{CONCLUSION}

Based on the laboratory bioassay studies, three promising isolates of entomofungal pathogens viz. NBAIR Ma-35 \& NBAIR Ma-4 of M. anisopliae and NBAIR $\mathrm{Bb}-5 \mathrm{a}$ of $B$. bassiana were identified against $P$. xylostella which can be further tested in the infested fields of cabbage and cauliflower.

\section{ACKNOWLEDGMENTS}

The authors are thankful to ICAR for financial support throughout the research and to the Director, NBAIR, Bangalore, India for providing facilities for undertaking the work.

Table 2. Details of promising isolates of $B$. bassiana and $M$. anisopliae against $P$. xylostella

\begin{tabular}{|l|l|l|l|l|}
\hline $\begin{array}{l}\text { Sl. } \\
\text { No. }\end{array}$ & Isolate Code & Genbank Accession number & Source & Location India \\
\hline 1. & NBAIR Bb5a & JF837134 & Hypothenemus hampei (Coffee berry borer) & Karnataka \\
\hline 2. & NBAIR Bb45 & JF837094 & Rhizosphere soil of Carrot & Tamil Nadu \\
\hline 3. & NBAIR Ma4 & JF837157 & Plocaederus ferrugineus (Cashew Stem Borer) & Karnataka \\
\hline 4. & NBAIR Ma35 & JQ518481 & Soil (Fallow land) & Gujarat \\
\hline
\end{tabular}

Table 3. Dose mortality response of entomopathogenic fungi against $P$. xylostella

\begin{tabular}{|l|c|c|c|c|c|c|}
\hline Isolates & $\mathbf{L C}_{\mathbf{5 0}}$ conidia/ $\mathbf{m l}$ & $\begin{array}{c}\mathbf{9 5 \%} \text { fiducial limit } \\
\text { (conidia/ml) }\end{array}$ & Slope \pm SE & $\mathbf{X}^{2}$ & P value & df \\
\hline $\begin{array}{l}\text { Metarhizium anisopliae } \\
\text { ICAR-NBAIR Ma-35 }\end{array}$ & $2.6 \times 10^{4}$ & $4.6 \times 10^{3}-7.6 \times 10^{4}$ & $0.572 \pm 0.106$ & 1.281 & 0.734 & 3 \\
\hline $\begin{array}{l}\text { Metarhizium anisopliae } \\
\text { ICAR-NBAIR Ma-4 }\end{array}$ & $5.3 \times 10^{4}$ & $1.1 \times 10^{4}-1.5 \times 10^{5}$ & $0.525 \pm 0.095$ & 0.453 & 0.929 & 3 \\
\hline $\begin{array}{l}\text { Beauveria bassiana } \\
\text { ICAR-NBAIR Bb-5a }\end{array}$ & $1.3 \times 10^{5}$ & $3.1 \times 10^{4}-3.6 \times 10^{5}$ & $0.500 \pm 0.087$ & 0.903 & 0.825 & 3 \\
\hline $\begin{array}{l}\text { Beauveria bassiana } \\
\text { ICAR-NBAIR Bb-45 }\end{array}$ & $1.9 \times 10^{6}$ & $5.7 \times 10^{5}-7.7 \times 10^{6}$ & $0.415 \pm 0.081$ & 0.574 & 0.902 & 3 \\
\hline
\end{tabular}

SE- standard error, $\mathrm{X}^{2}$ - Chi square, df- degree of freedom 
Bathina Poornesha and Bonam Ramanujam

Table 4. Time mortality response of entomopathogenic fungi against $P$. xylostella

\begin{tabular}{|c|c|c|c|c|c|c|}
\hline Isolates & $\mathbf{L T}_{50}$ hours & 95\% fiducial limit (hours) & Slope \pm SE & $\mathbf{X}^{2}$ & $P$ value & df \\
\hline $\begin{array}{l}\text { Metarhizium anisopliae } \\
\text { ICAR-NBAIR Ma-35 }\end{array}$ & 86.6 & 71.91-119.36 & $4.105 \pm 0.958$ & 1.165 & 0.761 & 3 \\
\hline $\begin{array}{l}\text { Metarhizium anisopliae } \\
\text { ICAR-NBAIR Ma-4 }\end{array}$ & 121.30 & $92.39-214.83$ & $2.928 \pm 0.705$ & 10.309 & 0.172 & 7 \\
\hline $\begin{array}{l}\text { Beauveria bassiana } \\
\text { ICAR-NBAIR Bb-5a }\end{array}$ & 100.32 & $84.04-132.67$ & $3.623 \pm 0.605$ & 4.038 & 0.846 & 5 \\
\hline $\begin{array}{l}\text { Beauveria bassiana } \\
\text { ICAR-NBAIR Bb-45 }\end{array}$ & 156.64 & $123.16-271.01$ & $3.276 \pm 0.800$ & 1.167 & 0.948 & 5 \\
\hline
\end{tabular}

SE- standard error, $\mathrm{X}^{2}$ - Chi square, df- degree of freedom

\section{REFERENCES}

Abbot WS. 1925. A method of computing effectiveness of insecticides. J Econ Entomol. 18:263-265. https://doi. org/10.1093/jee/18.2.265a.

Bert U. 2006. Development of sustainable control of diamondback moth in cabbage and cauliflower by public-private partnership. In: 'Science and Technology Policy for Development, Dialogues at the Interface' by Louk Box and Rutger Engelhard (eds) Anthem Press London UK.

Chui-Chai N, Krutmuang P, Nalumpang S, Mekchay S, Khanongnuch C, Chanbang Y. 2012. Insecticidal activity and cuticle degrading enzymes of entomopathogenic fungi against Plutella xylostella (Lepidoptera: Plutellidae). J. Nat. Sci. 11(1): 147-155.

Duarte RT, Gonçalves KC, Espinosa DJL, Moreira LF, De Bortoli SA, Humber RA, Polanczyk RA. 2016. Potential of entomopathogenic fungi as biological control agents of diamondback moth (Lepidoptera: Plutellidae) and compatibility with chemical insecticides. J. Econ. Entomol. 109(2):594-601. https://doi.org/10.1093/jee/ tow008. PMid: 26850733.

Furlong MJ, Wright DJ, Dosdall LM. 2013. Diamondback moth ecology and management: Problems, progress, and prospects. Annu. Rev. Entomol. 58:517-541. https:// doi.org/10.1146/annurev-ento-120811-153605. PMid: 23020617.

Liu MY, Sun CN. 1984. Rearing diamondback moth (Lepidoptera: Plutellidae) on rape seedlings by a modification of the Koshihara and Yamada method. $J$. Econ. Entomol. 77:1608-1609. https://doi.org/10.1093/ jee/77.6.1608.

Liu TX, Sparks AN, Chen W. 2003. Toxicity, persistence and efficacy of indoxacarb and two other insecticides on
Plutella xylostella (Lepidoptera: Plutellidae) immature in cabbage. Int. J. Pest. Manage. 49:235-241. https://doi. org/10.1080/0967087031000101070.

Loc NT, Chi VTB. 2007. Biocontrol potential of Metarhizium anisopliae and Beauveria bassiana against diamondback moth, Plutella xylostella. Omon. Rice. 15:86-93.

Maurer P, Couteaudier Y, Girard PA, Bridge PD, Riba G. 1997. Genetic diversity of Beauveria bassiana and relatedness to host insect range. Mycol. Res. 101:159164. https://doi.org/10.1017/S0953756296002213.

McCann SF, Annis GD, Shapiro R, Piotrowski DW, Lhm GP, Long JK, Lee KC, Hughes MM, Myers BJ, Griswold SM. 2001. The discovery of indoxacarb: Oxadiazines as a new class of pyrazoline-type insecticides. Pest Manage Sci. 57:153-164. https://doi.org/10.1002/15264998(200102)57:2<153::AID-PS288>3.0.CO;2-O.

Mohan M, Gujar GT. 2003. Local variation in susceptibility of diamond back moth to insecticides and role of detoxification enzymes. J. Crop. Prot. 22:495-504. https://doi.org/10.1016/S0261-2194(02)00201-6.

Sheeba G, Seshardi S, Raja N, Janarthana S, Ignacinutha S. 2001. Efficacy of Beauveria bassiana for control of the rice weevil Sitophilus oryzae L. (Coleoptera: Curculionidae). Appl. Entomol. Zool. 36:117-120. https://doi.org/10.1303/aez.2001.117.

Silva VCA, Barros R, Marques EJ, Torres JB. 2003. Suscetibilidade de Plutella xylostella (L.) (Lepidoptera: Plutellidae) aos fungos Beauveria bassiana (Bals.) Vuill. e Metarhizium anisopliae (Metsch.) Sorok. Neotrop Entomol. 32:653-658. https://doi.org/10.1590/ S1519-566X2003000400016.

Suwannakut S, Boucias DG, Wiwat C. 2005. Genotypic analyses of Nomuraea rileyi collected from various 
Evaluation of Beauveria bassiana and Metarhizium anisopliae isolates against Plutella xylostella

noctuid hosts. J. Invert. Pathol. 90:169-176. https://doi. org/10.1016/j.jip.2005.08.010. PMid: 16253269.

Valda CA, Silva RB, Edmilson JM, Jorge BT. 2003. Susceptibility of Plutella xylostella (L.) (Lepidoptera: Plutellidae) to fungus Beauveria bassiana (Bals.) Vuill and Metarhizium anisopliae (Metsch.) Sorok. Neotropical Entomol. 32(4):653-658. https://doi. org/10.1590/S1519-566X2003000400016.
Zalucki MP, Shabbir A, Silva R, Adamson D, Shu-Sheng L, Furlong MJ. 2012. Estimating the economic cost of one of the world's major insect pests, Plutella xylostella (Lepidoptera: Plutellidae): Just how long is a piece of string? J. Econ. Entomol. 105(4):1115-1129. https://doi. org/10.1603/EC12107. PMid: 22928287. 